\title{
Spatiotemporal expression profiling of proteins in rat sciatic nerve regeneration using reverse phase protein arrays
}

\author{
David J Bryan ${ }^{1,6^{*}}$, C Robert Litchfield ${ }^{1 \dagger}$, Jeffrey V Manchio ${ }^{1,5}$, Tanya Logvinenko ${ }^{3}$, Antonia H Holway ${ }^{2,4}$,
} John Austin ${ }^{4}$, lan C Summerhayes ${ }^{2}$ and Kimberly M Rieger-Christ ${ }^{2}$

\begin{abstract}
Background: Protein expression profiles throughout 28 days of peripheral nerve regeneration were characterized using an established rat sciatic nerve transection injury model. Reverse phase protein microarrays were used to identify the spatial and temporal expression profile of multiple proteins implicated in peripheral nerve regeneration including growth factors, extracellular matrix proteins, and proteins involved in adhesion and migration. This highthroughput approach enabled the simultaneous analysis of 3,360 samples on a nitrocellulose-coated slide.

Results: The extracellular matrix proteins collagen I and III, laminin gamma-1, fibronectin, nidogen and versican displayed an early increase in protein levels in the guide and proximal sections of the regenerating nerve with levels at or above the baseline expression of intact nerve by the end of the 28 day experimental course. The 28 day protein levels were also at or above baseline in the distal segment however an early increase was only noted for laminin, nidogen, and fibronectin. While the level of epidermal growth factor, ciliary neurotrophic factor and fibroblast growth factor- 1 and -2 increased throughout the experimental course in the proximal and distal segments, nerve growth factor only increased in the distal segment and fibroblast growth factor- 1 and -2 and nerve growth factor were the only proteins in that group to show an early increase in the guide contents. As expected, several proteins involved in cell adhesion and motility; namely focal adhesion kinase, $\mathrm{N}$-cadherin and $\beta$-catenin increased earlier in the proximal and distal segments than in the guide contents reflecting the relatively acellular matrix of the early regenerate.
\end{abstract}

Conclusions: In this study we identified changes in expression of multiple proteins over time linked to regeneration of the rat sciatic nerve both demonstrating the utility of reverse phase protein arrays in nerve regeneration research and revealing a detailed, composite spatiotemporal expression profile of peripheral nerve regeneration.

Keywords: Peripheral nerve regeneration, Reverse phase protein array, Extracellular matrix, Proteomics, Growth factors

\section{Background}

Peripheral nerve injury has been estimated to occur in about $3 \%$ of trauma patients and can lead to life-long disability [1]. Transection injuries, especially those that result in large gaps between nerve ends, are particularly incapacitating. While the peripheral nervous system has

\footnotetext{
* Correspondence: david.j.bryan@lahey.org

+ Contributed equally

${ }^{1}$ Tissue Engineering Laboratory, Lahey Clinic Medical Center, Burlington,

Massachusetts, USA

Full list of author information is available at the end of the article
}

the ability to regenerate, transection injuries typically require reconstructive surgery and the restoration of sufficient function remains a significant challenge.

Regeneration in the peripheral nervous system is a complex process which requires the careful orchestration of multiple factors and cues to create the optimal microenvironment for regeneration to occur [reviewed in [2] and [3]]. Past research has shown that axons regenerate from the proximal stump of a transected nerve in response to tactile signals and chemotropic

\section{() Biomed Central}


secretions from the distal stump of the severed nerve $[4,5]$. The cellular events underlying serial stages in peripheral nerve regeneration have been described and include Wallerian degeneration of the distal nerve followed by regeneration events led by the migration of Schwann cells from the distal nerve segment and axon sprouting from the proximal nerve segment forming the proximal growth cone [reviewed in [6] and [7]]. These axons use bands of Büngner, formed by proliferating Schwann cells extending from the distal stump, as a physical scaffold to guide their growth. Recently, Parrinello and colleagues reported that fibroblasts also play a key role in peripheral nerve regeneration. More specifically, they have shown that when the nerve is severed, ephrin-B/EphB2 signaling between fibroblasts and Schwann cells results in cell sorting, followed by directional collective cell migration of Schwann cells out of the nerve stumps to guide regrowing axons cross the wound [8]. The axons and Schwann cells both respond to and produce, trophic factors which are transported to the injury site where they have growth potentiating effects; attracting axons in a concentration guided, modality-specific and organ-specific manner [9-12]. The role of Schwann cells following axotomy is multifaceted including initial phagocytosis of cell debris followed by the transfer of degraded myelin to macrophages, as part of the degenerative process. The migration of Schwann cells precedes the involvement of alternative cell populations activated by signals presumably released by the cells of the proximal growth cone that in turn respond to triggers occurring physically downstream. Such cues for migration include growth factors and extracellular matrix (ECM) proteins as has been demonstrated in in vitro models of migration [13-15].

The underlying events that drive the regenerative process have yet to be fully elucidated; although there has been extensive research looking at both inhibitory and promotional factors. Peripheral nerve regeneration research efforts can be generally divided into two categories, those that evaluate materials used to create a physical scaffold or nerve guide to direct the regenerating nerve (also referred to as tubulation) [16] and those that alter the environment of the regenerating nerve. Environmental alteration, for example through the use of cultured cells or growth factors, is often combined with a guide, to create an optimal regenerative environment [reviewed in [17] and [18]]. While early studies used conduits composed of decalcified bone, more recent guides have consisted of a range of synthetic and biological materials [reviewed in [17] and [18]]. The ideal guide material is one that retains sufficient mechanical strength for surgical manipulation while providing permeability and bioresorbability so as not to act as a barrier for cell infiltration and nerve regeneration [[19-24] and others].
While many studies have shown promising results, they have yet to produce an alternative that is superior to the nerve autograft, the current gold standard. Although autografting is the standard of care when repairing loss of length of large multifascicular nerve injuries, it is not without disadvantages, namely neuroma formation, unavailability of donor nerve, conflicts of modality and donor site morbidity [25-28].

Research focused on altering the microenvironment of the regenerating nerve has also shown promise. A number of molecules have been shown to enhance nerve regeneration including nerve growth factor (NGF) [29-32], fibroblast growth factor (FGF) [33-37], glial growth factor [38], platelet-derived growth factor [39], ciliary neurotrophic factor (CNTF) [40-43] and ECM components such as fibronectin, collagen and laminin [44-49]. The action of each class of molecule can be direct, influencing axon growth by binding to axonal cellular components or indirect by guiding axon growth and modeling a microenvironment permissive for the promotion of regeneration. Despite the advances reported in experimental models which have combined the different facets of polymer guides and the delivery of relevant molecules directly to the regenerative site, full functional restoration has not been attained. The events underlying peripheral nerve regeneration represent tightly orchestrated interactions between a diverse array of molecules within a tightly regulated temporal sequence. Thus it is difficult to adopt a reductionist approach to understand such a complex series of events.

To further enhance our understanding of the regenerative process it would be beneficial to gain a more global view of the cellular and biochemical events that underlie peripheral nerve regeneration from both a spatial and temporal perspective by evaluating protein expression in different segments of the regenerating nerve over time. Proteomic techniques such as Western blots and immunohistochemistry haven been used successfully for spatiotemporal profiling, but these techniques are typically low-throughput and most reports focus on just a few proteins. Due to differences in experimental models, it is difficult to combine observations between studies. Proteomics techniques such as two-dimensional gel electrophoresis and mass spectrometry have been instrumental in identifying candidate proteins involved in peripheral nerve regeneration and have demonstrated the complexity of protein expression in the regenerating nerve [50-53]. The reverse phase protein array (RPPA) is a powerful proteomic technique that enables the measurement of protein levels in a large number of samples simultaneously [54-60]. By arraying lysates created from distinct portions of the regenerating nerve at distinct time points we were able to create a spatiotemporal expression profile of the peripheral nerve regeneration 
process on a single microscope slide. Each slide requires only a small amount of lysate ( $2 \mathrm{nl}$ per spot), so the material from a single experiment can be used to evaluate the expression profile of hundreds of proteins.

In this study we evaluate the use of RPPAs in peripheral nerve regeneration using an established rat sciatic nerve transection injury model combined with a polyethylene nerve guide. The non-permeable, non-degradable polyethylene guide was selected for this study over a resorbable guide to simplify the harvesting of regenerated tissue. Previous studies by our group using this model have reproducibly resulted in regenerated nerve cables within 4-8 weeks [61] and the series of events leading to regeneration in a similar silicone guide model are well described [62]. The expression of 15 proteins known to be involved in various aspects of the regenerative process including growth factors, ECM proteins, and adhesion and motility proteins was profiled in multiple locations and at multiple time points.

\section{Results}

Validation of antibodies for use in RPPA

All antibodies were tested for their suitability for use in RPPA by western blot analysis (Figure 1 and data not shown). Total protein lysates from excised nerves were pooled and separated by gel electrophoresis. Confirmation of the utility of each antibody for use in the RPPA setting was determined by the detection of a single predominant band by western blot. An example blot with a representative selection of the antibodies used is shown in Figure 1.

\section{Reverse phase protein arrays}

The proximal and distal ends of the severed sciatic nerve, along with the solid contents of the guide, were harvested at different time points following axotomy and tissue was prepared for RPPA. Tissue lysates were arrayed in a 10-point, 2-fold dilution series on a single nitrocellulose-coated microscope slide, with tissue controls corresponding to the day 0 excised sciatic nerve

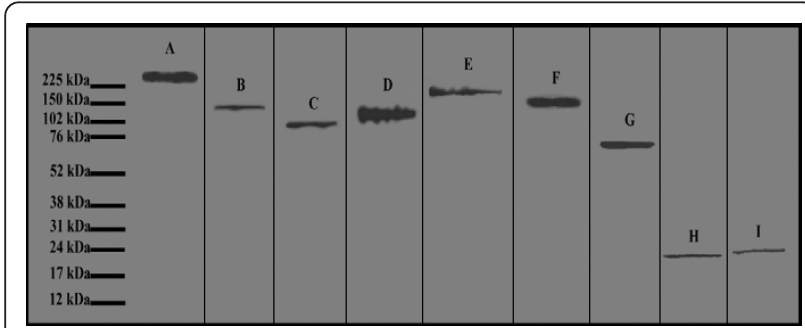

Figure 1 Antibody Validation: Validation of selected antibodies in western blot analysis showing detection of a single band for fibronectin (A), $\mathrm{N}$-cadherin (B), $\beta$-catenin (C), E-cadherin (D), laminin $\gamma-1(\mathbf{E})$, nidogen $(\mathbf{F})$, versican $(\mathbf{G})$, FGF-2 $(\mathbf{H})$, and CNTF (I). from that animal. All samples from all animals used in this study were printed on every slide. The expression level of 15 different proteins was measured in the tissue lysate preparations. Figure 2 shows the processed RPPA for growth associated protein 43 (GAP-43) (A) as well as the extrapolated protein level as a function of time for each of the regions (proximal, guide and distal) (B).

\section{Expression profile of the selected protein panel throughout nerve regeneration}

Protein expression profiles throughout the 28 day experimental period are displayed in Figures 3, 4, and 5. The antibody panel selected for this study is divided into three groups. The first group is adhesion and cell motility consisting of $\mathrm{E}$ - and $\mathrm{N}$-cadherin, $\beta$-catenin, and focal adhesion kinase (FAK) (Figure 3). The growth factors NGF, FGF-1, FGF-2, epidermal growth factor (EGF) and CNTF comprise the second group (Figure 4). ECM proteins laminin, fibronectin, collagen I/III, nidogen and versican make up the third group (Figure 5). While

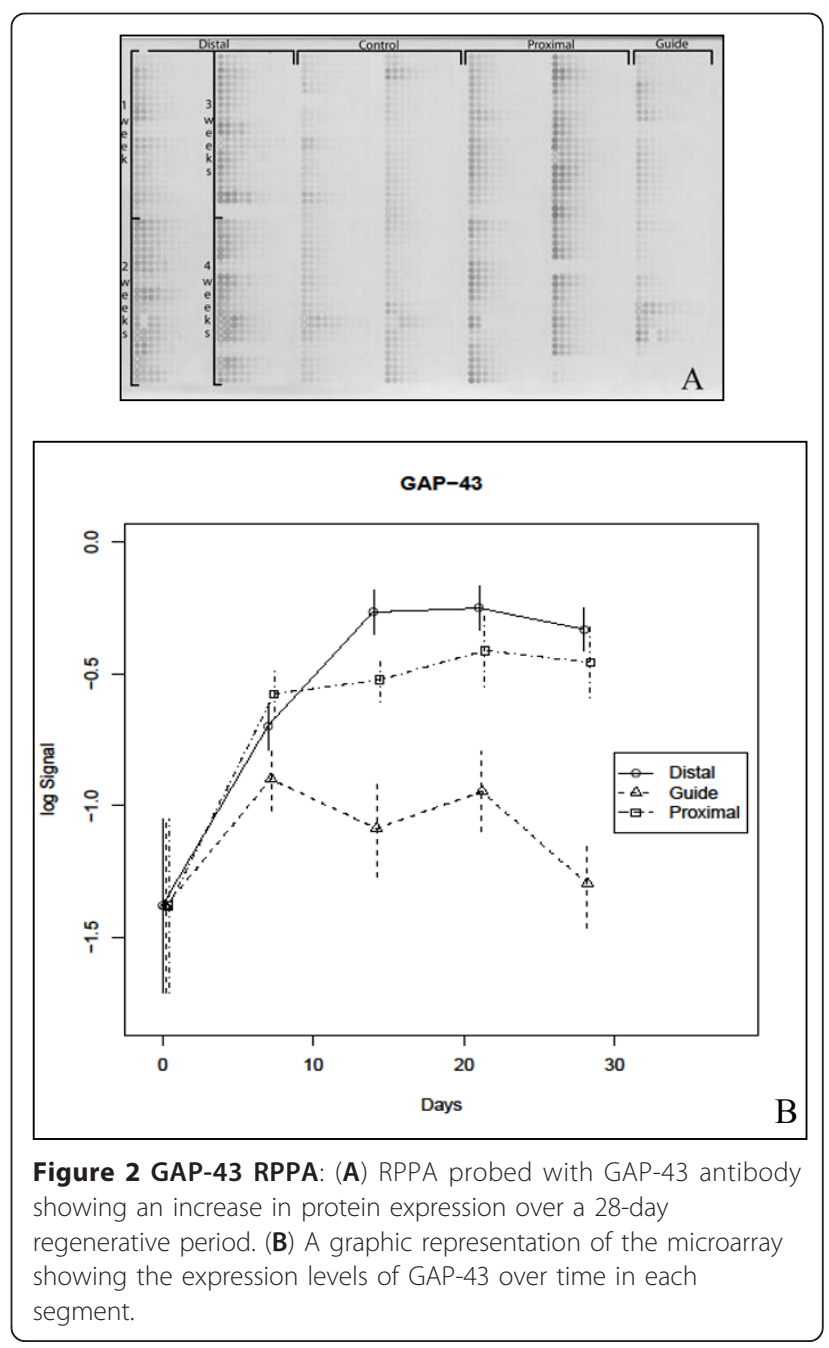



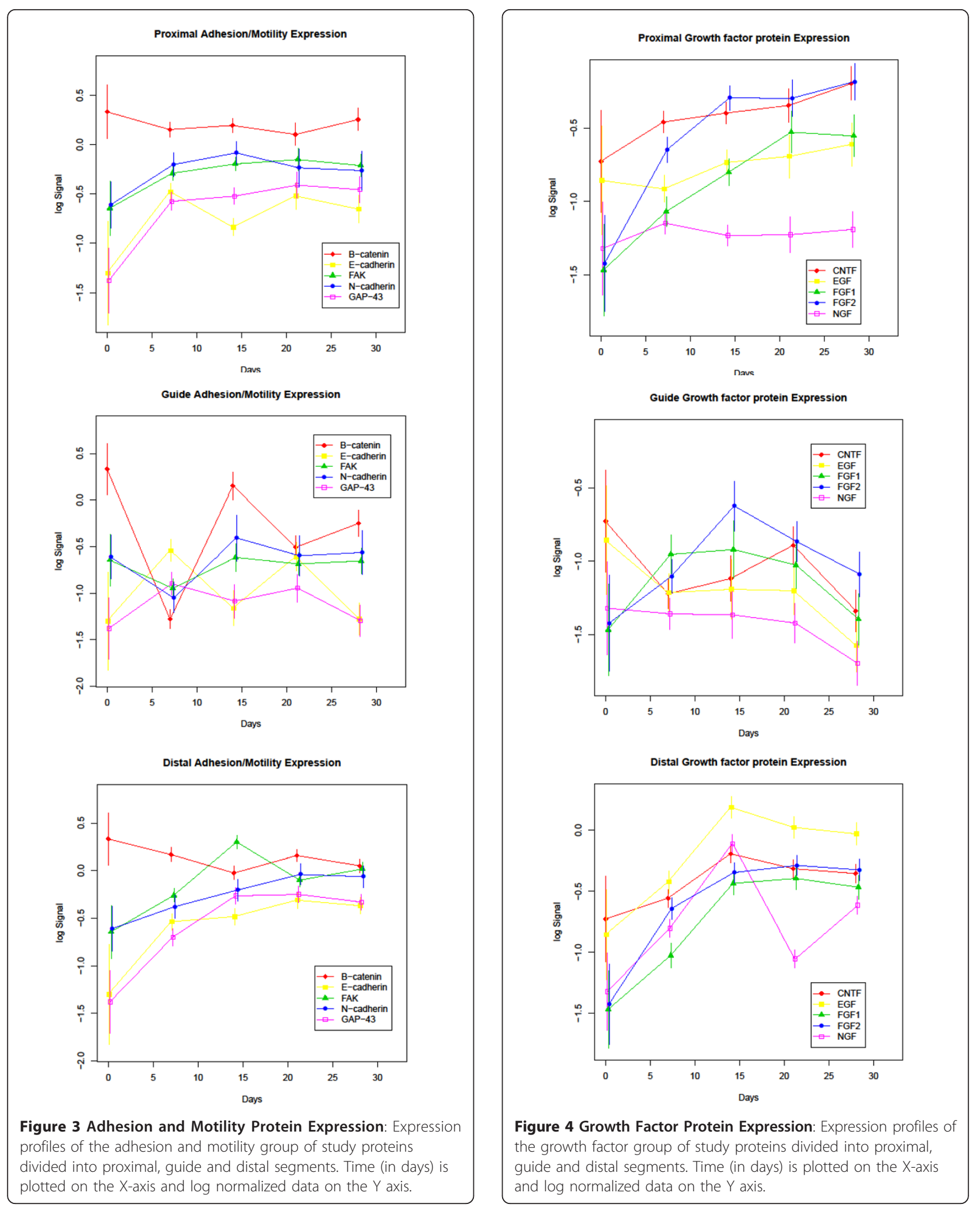


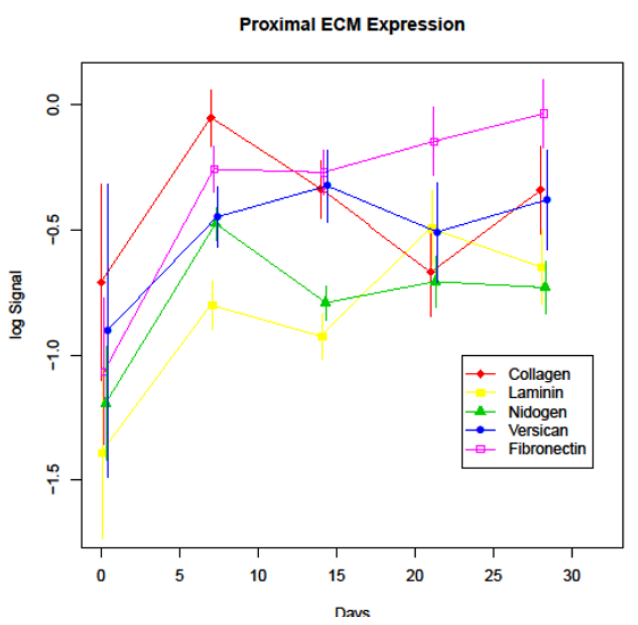

Guide ECM Expression

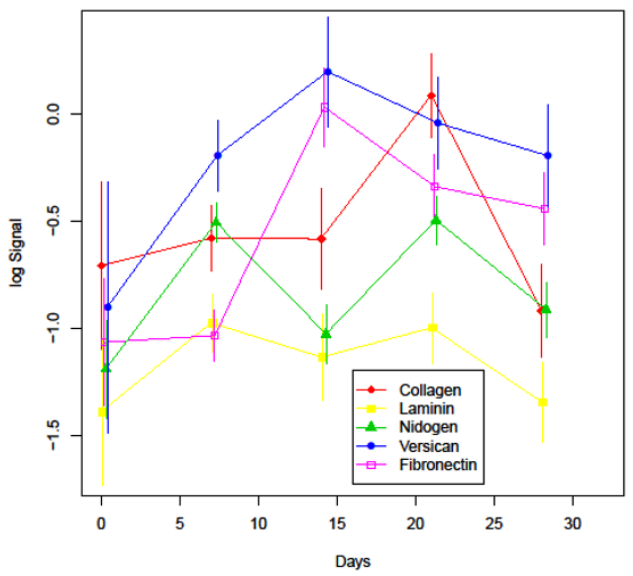

Distal ECM Expression

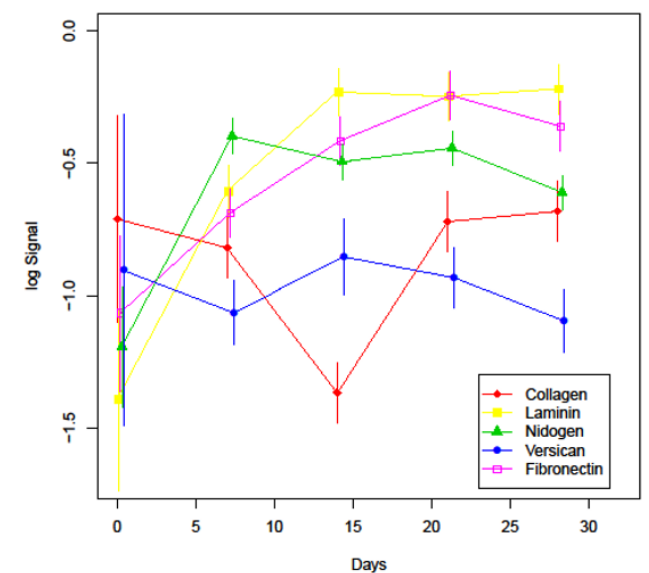

Figure 5 ECM Protein Expression: Expression profiles of the ECM group of study proteins divided into proximal, guide and distal segments. Time (in days) is plotted on the X-axis and log normalized data on the $Y$ axis.
GAP-43 plays direct roles in different aspects of nerve regeneration with functional effects spanning more than one of these groups, it is grouped with the adhesion and motility proteins. A summary of expression of the complete panel of proteins under study is shown in Figure 6 presented in a heatmap format.

\section{Adhesion/motility associated proteins}

Members of the classic cadherin family, E- and N-cadherin, displayed an overall increase in expression throughout the course of regeneration. In the proximal and distal segments of the regenerating nerve this increase was significant for E-cadherin when the expression level from day 0 (intact nerve) was compared with day 28 (q-values of 0.022 and 0.002 respectively). The change in $\mathrm{N}$-cadherin expression between day 0 and day 28 was significant in the distal portion only (q-value 0.036). Interestingly, the levels of $\mathrm{N}$-cadherin in the proximal segment appeared to peak at day 14 and the expression level at 14 days was significantly higher than baseline (q-value 0.024). Both E-cadherin and N-cadherin displayed continued elevated expression up to 21 days in the distal segment followed by a plateau in expression up to 28 days. There was no significant change in $\mathrm{E}$ - or $\mathrm{N}$-cadherin levels in the guide contents when comparing the day 0 to the day 28 time point. The guide segment results compare intact nerve (day 0 expression levels) to the regenerate which, at least for the early time points, contains no nerve. Since the guide segment contains only regenerated tissue, the lack of significant difference from day 0 represents a return to the baseline protein levels seen in intact nerve. For $\mathrm{N}$ cadherin this return to baseline occurs by day 14 while fluctuations in E-cadherin expression were recorded throughout the 28 day regenerative period with above baseline peaks at $\leq 7$ and 21 days and troughs that approached baseline levels at 14 and 28 days. In contrast, $\beta$-catenin, an integral member of the cadherin complex, showed a significant change from baseline only at day $\leq 7$ in the proximal (q-value 0.024 ) and distal (q-value 0.029) segments, but in the guide tissue displayed peaks and troughs that mirrored $\mathrm{N}$-cadherin, but were opposite to that recorded for E-cadherin in the same site.

FAK has been shown to promote neurite outgrowth and in this model displayed an increase in expression throughout the regenerative process in the proximal and distal segments with an initial, significant drop at day $\leq$ 7 (q-value 0.002) and recovery to higher than baseline levels by day 14 in the guide portion. The overall 


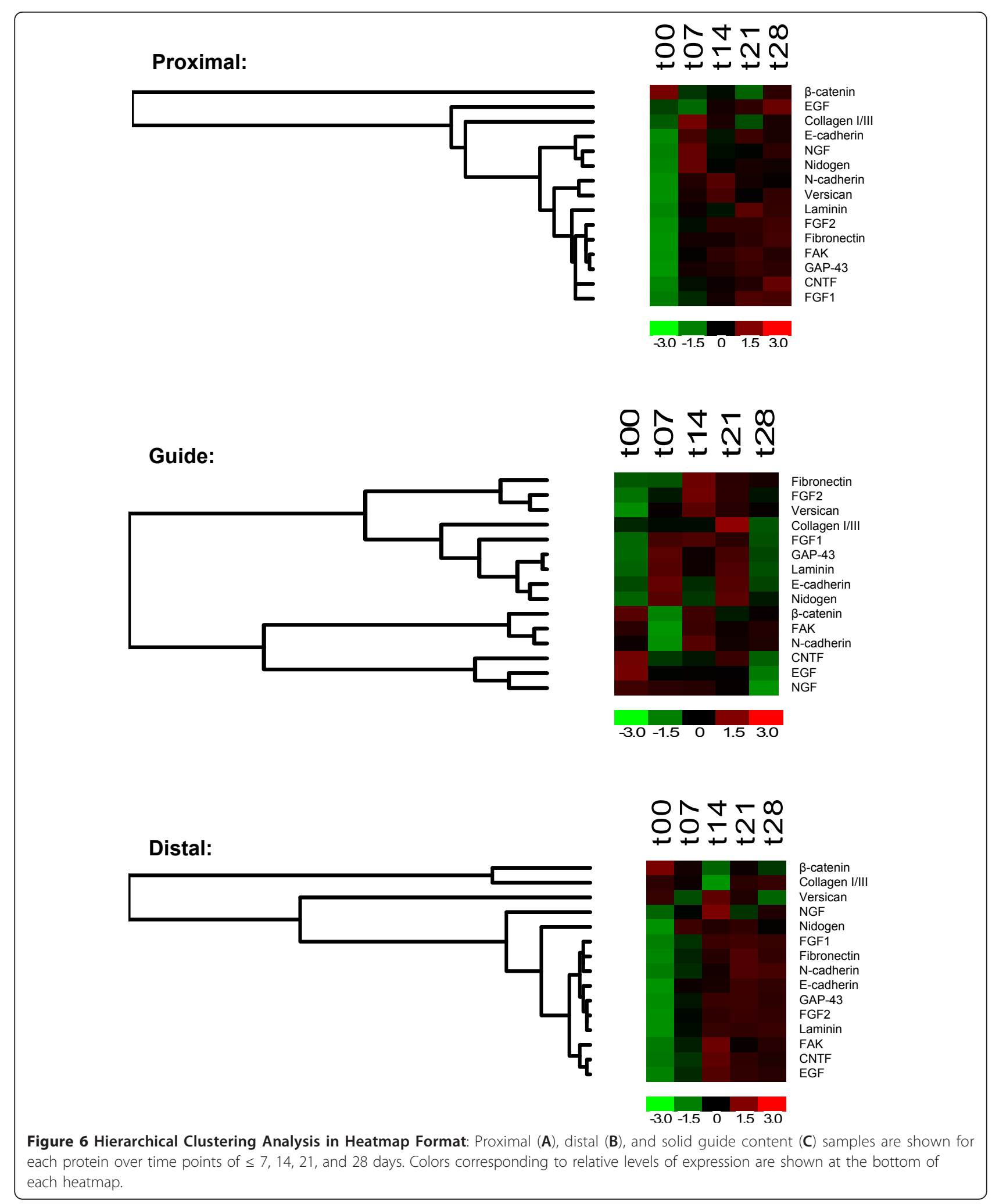


increase in FAK levels between day 0 and day 28 was significant in the distal segment only (q-value 0.016).

In the distal nerve stump GAP-43 levels increased rapidly up to 14 days followed by a relative plateau for the remainder of the experimental course. A sharp increase in GAP-43 was also seen in the proximal nerve up until 7 days with a slower, but marked increase through 28 days. In contrast, GAP-43 protein level showed no significant change from baseline throughout the course of the experiment in the guide contents indicating an early up-regulation of GAP-43 in the regenerating tissue. The overall increase in GAP-43 between day 0 and day 28 was significant in the proximal and distal segments only (q-values 0.002 and 0.001 respectively).

\section{Growth factors}

Amongst the molecules included in the growth factor group, a significant increase in the expression level of FGF-1, FGF-2 and EGF was recorded between 0-14 days in the regenerating distal nerve followed by a plateau in expression between 14 and 28 days (the q-value for the day 0 to day 14 comparisons were $0.007,0.004$, and 0.009 respectively). In the proximal nerve segment, expression levels of each of the aforementioned growth factors continued to rise past 14 days although none of the changes after day 14 reached significance. Comparing day 0 to day 28, both FGF-1 and FGF-2 demonstrated a significant increase in protein levels in the proximal nerve segment, but EGF did not (q-values for FGF-1 and FGF-2 were 0.006 and $<0.001$ respectively). Interestingly, significantly reduced EGF expression was recorded in the guide tissue over the 28 day regeneration period ( $q$-value $<0.001$ ). In contrast, a comparison of day 0 to day 28 protein levels for FGF-1 and FGF-2 did not reveal a significant change in the guide contents indicating a return to the baseline levels of intact nerve and both proteins displayed a temporary increase in expression that peaked at 14 days and reached significance for FGF-2 (q-value 0.037).

CNTF displayed only a limited, insignificant increase in expression in the proximal and distal segments relative to the other growth factors in the study and, like EGF, significantly reduced expression in the guide tissue between day 0 and day 28 (q-value < 0.001). However, unlike EGF, CNTF did not decrease throughout the entire regenerative period, instead displaying an increase in expression at 21 days followed by a further decline at 28 days.

NGF displayed a biphasic expression profile in the regenerating distal nerve with significant peaks occurring at 14 and 28 days post-axotomy (q values $<0.001$ and 0.006 respectively when comparing day 14 and day 28 to baseline). No significant change in NGF expression was recorded in the proximal segment or guide compartment of the regenerating nerve between baseline and day 28. In the guide compartment the level of NGF was not significantly different than baseline by day $\leq 7$ indicating an early recovery of NGF protein in this segment.

\section{Extracellular matrix proteins}

The ECM proteins have been shown to play a role in growth promotion and cell migration involving directional guidance, both important processes in nerve regeneration. Fibronectin displayed a significant increase in protein levels over baseline at 21 and 28 days in the proximal segment (q-values 0.014 and 0.024 respectively), 21 days in the distal segment (q-value 0.036), and even at the earliest time point of $\leq 7$ days no significant change from intact nerve in the guide segment. A significant increase from baseline levels was observed in the guide segment at day 14 and day 21 (q-values < 0.001 and 0.023 respectively). Laminin displayed a significant increase in both the proximal and distal segments between 0 and 28 days (q values 0.009 and < 0.001 respectively), whereas the guide contents did not show a significant change when comparing the same time points indicating a return to the levels of intact nerve. Like fibronectin, day $\leq 7$ laminin expression was also not significantly different than baseline in the guide segment. Collagen I/III had a distinct temporal sequence of expression which peaked at days $\leq 7$ and 21 in the proximal and guide segments, respectively, and was significantly reduced compared to baseline in the distal segment (q-value 0.011 ) at 14 days followed by restoration to expression levels recorded in the intact nerve for the remainder of the experimental course. At day $\leq 7$ the guide segment had recovered to baseline collagen I/ III expression levels. Nidogen and versican protein levels were elevated overall although the change was only significant in the distal segment (q-values for both comparisons were 0.014). Nidogen, a potentiator of Schwann cell proliferation, showed biphasic expression with peaks at $\leq 7$ and 21 days post-axotomy most notably in the guide segment indicating an early increase even higher than baseline expression. Versican protein levels were elevated early in the proximal and guide segments with a significant increase at 14 days ( $q$-values 0.011 and $\leq$ 0.001 respectively) followed by a slow decline with levels increased, but not significantly different than baseline at 28 days. In the distal segment protein levels were significantly lower than baseline at day $\leq 7$ and day 28 (qvalues 0.018 and 0.014 respectively).

\section{Discussion}

Significant advances in promoting peripheral nerve regeneration have been made on multiple fronts including the use of bioresorbable polymer guides to serve as conduits and delivery devices for different molecules 
that have been implicated as promotional in the regenerative process. Knowledge of the expression pattern of proteins essential to regeneration have helped predict the best candidates for exogenous administration, however this information must be pooled from individual studies with variable models in order to generate a global expression profile. In this study we used RPPA to facilitate the simultaneous temporal and spatial expression mapping of key proteins in the nerve regeneration process using a rat sciatic nerve transection injury model. The benefit of RPPA analysis is that many samples can be analyzed simultaneously. Since this technique requires very little starting material, it also enables the analysis of a large number of proteins. The limited number of proteins reported in this study was not due to a limitation in source material, but instead the limited availability of antibodies that cross-react with rat proteins and were suitable for use in RPPA. In this study every antibody was first validated by western blot and any antibody that did not produce a single predominant band by western was excluded. Although an analysis of 15 proteins does not represent the full capability of the RPPA technique, we believe that this paper provides significant insight into the regulation of these proteins and sets the stage for further proteomic evaluation using this model.

The phases of regeneration in a non-permeable, nonresorbable nerve guide chamber have been described and include a fluid, matrix, cellular, and axonal phase [62]. Within a day after axotomy and guide insertion the guide fills with fluid that contains neuronotrophic factors. A mainly acellular matrix forms within a week followed by the immigration of cells (including Schwann, fibroblast, and endothelial) from both the proximal and distal nerve stumps after 7-14 days. Finally, after 2 weeks, axonal elongation begins with myelination occurring a few days later [62]. According to this description, the first time point used in the current study ( $\leq 7$ days) would capture the regenerative process at the matrix phase with the second time point (14 days) representing the cellular phase. The final time points of 21 and 28 days represent the axonal phase with the later time point likely to have a higher percentage of myelinated axons.

Protein expression analysis in the guide content compares intact nerve (day 0 expression levels) to the regenerate which initially contains no nerve. Based on the described regenerative process, an early increase (manifested as a return to baseline levels) in the proteins included in the ECM category would be expected in the guide portion of the regenerate. Indeed, all of the ECM proteins studied demonstrate not only a return to baseline, but an increase in expression at $\leq 7$ days over intact nerve. In contrast, several of the cellular proteins such as $\beta$-catenin, FAK, and $\mathrm{N}$-cadherin show an initial decline from the protein level of intact nerve in the guide segment and peak later at day 14 corresponding with the cellular phase of regeneration. This initial decline from baseline is to be expected since the guide segment does not contain intact nerve at the earlier time points. Interestingly, the growth factors represent a mixed group in the guide portion with an early return to baseline or increase over intact nerve for NGF, FGF-1 and FGF-2, and overall decline in the levels of CNTF and EGF in the solid guide contents. Overall, we saw a decrease in the expression of all growth factors in the guide contents from day 21 to day 28 , the time at which axonal migration and myelination is underway. This is consistent with a previous study that demonstrated that the neuronotrophic activity of the fluid that fills the guide chamber is highest in the first few days of regeneration suggesting that the role of at least some of these molecules peaks early in the regenerative process [63]. The general patterns of protein expression seen by RPPA analysis in this study are consistent with established knowledge and warrant more thorough analysis.

GAP-43 is present in the presynaptic terminal of novel neuromuscular junctions [64], and has been shown to be expressed in regenerating axons following nerve injury [65-68]. GAP-43 reportedly plays a promotional role in nerve sprouting post axotomy [69]. In our model we found an overall increase in GAP-43 levels throughout the experiment. Several groups have reported an early up-regulation of GAP-43 protein or mRNA following nerve injury $[68,70,71]$. We observed a pattern of early, increased expression in both the proximal and distal nerve segments that appeared to plateau by 14 days. At its peak, the distal nerve segment has a higher expression level of GAP-43 than the proximal nerve and the guide contents show no significant change in GAP-43 compared to intact nerve even at the earliest time point. These results differ slightly than those of Plantinga et al. who reported no increase in proximal GAP-43 mRNA levels, but this difference might be explained by differences in the experimental models, most notably that the nerve ends in the former study were coagulated and ligated while ours were allowed to regenerate. The discrepancy could also be explained by poor correlation between mRNA and protein levels [68].

Members of the cadherin family and the associated proteins that form the functional cadherin/catenin complex have been shown to play important roles in cell migration. E-cadherin is associated with the adherens junctions of the Schmidt-Lanterman incisures and is unique because it forms an autotypic adherens-type junction confined to the plasma membrane of a single Schwann cell [72]. Expression of E-cadherin is increased following injury in a variety of models $[73,74]$. Consistent with these studies, we found elevated expression of 
E-cadherin in all segments at the day $\leq 7$ time point. In the distal and proximal segments, day 28 levels remain significantly higher than baseline while in the guide they return to the baseline level of intact nerve.

As cadherin complexes assemble, there is a distinct hierarchy of catenin association led by E-cadherin/ $\beta$ catenin binding followed by additional catenin members. Interestingly, $\beta$-catenin that binds to E-cadherin within the cadherin complex, revealed no significant change in expression profile throughout the regenerative process in the proximal and distal segments in our study. $\beta$ catenin levels in the guide decreased significantly at $\leq 7$ days followed by a rebound to baseline levels and a significant but lower decline from baseline at 21 and 28 days. Our observation is in contrast to a report by Hatoko et al. that showed increased $\beta$-catenin expression in the graft portion of a nerve graft model of regeneration, however this difference might be explained by the fact that the previous study was evaluating expression in intact nerve grafts where our study included just the regenerated contents within a hollow guide [75].

$\mathrm{N}$-cadherin has been shown to be present on axonal growth cones in vitro [76] and is thought to play a role in the stabilization of myelin sheaths based on its distribution and low expression levels in normal nerves $[77,78]$. Several groups have reported increased N-cadherin levels at 15 days post-axotomy $[79,80]$. We confirmed an increase in $\mathrm{N}$-cadherin expression during regeneration that reached statistical significance at 14 days in the proximal segment and 21 days in the distal segment, but did not observe significantly higher expression in the distal segment than the proximal segment as reported by Thorton and colleagues [80]. This discrepancy may be explained by differences in the models used where in the Thorton study the nerve ends were capped following axotomy and not allowed to regenerate. We also showed that in the distal stump, N-cadherin expression peaks at 21 days which is later than the 14 day peak in the proximal segment and suggests a temporal sequence of events. The guide contents show an initial (day $\leq 7$ ) decrease in $\mathrm{N}$-cadherin expression followed by a higher than baseline peak at 14 days and slight decline similar to the pattern observed in the proximal segment. Since N-cadherin has been shown to be expressed around regenerated axons [79,81], the drop in $\mathrm{N}$-cadherin expression in the guide contents at day $\leq$ 7 is likely due to the absence of axon-axon or axonSchwann cell interactions at this location at such an early stage in the regenerative process.

FAK has been identified as a regulator of Schwann cell proliferation in the developing nervous system [82] and inhibition of FAK activity inhibited neurite growth in an in vitro model [83]. In the current study, FAK expression was increased in both the distal and proximal nerve segments although only the increase in the distal portion reached statistical significance. In the guide there was a drop in FAK levels at day $\leq 7$, likely due to the absence of intact nerve and corresponding reduction in Schwann cells at this time point, followed by a return to baseline for the remainder of the experiment. Activation of FAK leads to autophosphorylation at Tyr397 and an analysis of activated FAK levels will be needed to further elucidate the role of FAK in regeneration.

Numerous growth factors have been implicated in peripheral nerve regeneration with different members of the FGF family playing a prominent role in this process [reviewed in [84] and [85]]. Several groups have reported enhancement of nerve regeneration using FGF-1 and -2 [33,34,86-89] and FGF-2 levels have shown to be up-regulated following peripheral nerve injury at both the mRNA and protein levels [[90-92] and others]. Surprisingly, a decrease in FGF-1 protein levels or mitogenic activity after crush or transection has also been reported [93,94]. We observed an increase in FGF-1 and FGF-2 levels in both the proximal and distal ends of the regenerating nerve. Interestingly, in our study, FGF-1, FGF-2, and NGF were the only growth factors to show an early increase in the guide contents suggesting that these factors play a role in the initial phase of the regenerative process.

While EGFR mRNA and protein levels increase following nerve injury [95], and an EGF homolog has been shown to promote axonal regeneration in CNS neurons in vitro [96], Dubuisson et al. found that exogenous EGF did not enhance peripheral nerve regeneration in their model [97]. We found that EGF protein levels were increased significantly in the distal segment. The proximal segment showed an insignificant increase and there was an overall decrease in EGF in the solid contents of the guide. This differential in EGF expression could imply a role for EGF in the maturation of peripheral nerve tissue rather than in the more active state of regeneration.

NGF is a neurotrophin that has been shown to play a role in nerve regeneration in a large number of studies. Rich et al. demonstrated improved peripheral nerve regeneration with added NGF, as have others [30-32,98]. NGF mRNA and protein has been shown to be expressed at low levels in healthy nerves and up-regulated in the distal, but not the proximal stump upon injury $[94,99]$. In our model NGF expression remained at baseline levels in the regenerating proximal segment. In contrast, NGF expression rapidly returned to the baseline level of intact nerve in the guide tissue and was significantly elevated in the distal segment by 14 days post-axotomy and at the end of the experiment following an unexplained dip at 21 days. This supports the earlier findings that NGF is linked to events in the guide and distal segment of the regenerating nerve. 
CNTF increases neuronal survival, neurite outgrowth, and axonal regeneration with exogenous administration $[41,42,100,101]$, but Ito and colleagues reported low CNTF mRNA levels post-axotomy and a similar observation has been made in a crush model [102,103]. In our study CNTF displayed only a limited, insignificant increase in expression in the proximal and distal segments and an overall significant decrease in protein levels within the solid guide contents consistent with these later reports.

ECM components play an essential role in nervous system development and repair. Schwann cells assemble a fibrillar network that consists of fibronectin, laminin, and collagen type IV which is thought to play a role in proliferation [104]. The different ECM proteins likely exert their influence on different facets of nerve regeneration influencing multiple cellular processes. Fibronectin has previously been shown to be a potent chemoattractant for Schwann cell migration in vitro and in vivo $[13,14,105,106]$ and fibronectin protein and mRNA levels were found to be elevated in several models of nerve injury [107-109]. We found an increase in fibronectin levels that reached significance at day 21 proximally and distally. Within the guide there was an early return to baseline levels by day $\leq 7$ and significant increase over baseline by day 14 . Fibronectin levels increased more rapidly in the proximal segment than the distal segment and were significantly higher at $\leq 7$ days in the proximal segment consistent with the findings of Lefcort et al. who demonstrated highest fibronectin expression in the vicinity of the injury at the same time point [107].

Laminins are key components of the basal lamina and laminin has been shown to play a prominent promotional role in nerve regeneration in vivo by regulating axonal growth $[110,111]$. The laminin gamma-1 (B2) chain is one of the most abundant of the 12 known chains that compose the laminin heterotrimer and is present in laminin isoforms 1-4 and 6-11 [112]. There is conflicting evidence regarding gamma-1 mRNA expression with Wallquist and colleagues showing an up-regulation after sciatic transection (most notably in the proximal stump) and Doyu et al. reporting a decrease when normalized to total RNA levels [113,114]. In our experiment, gamma-1 protein expression increased significantly between day 0 and day 28 both proximally and distally, and there was an early return to baseline gamma-1 levels in the guide itself. Our results are most consistent with those of Wallquist [113]. In both our model and the Wallquist model the nerve ends were allowed to regenerate, while in the Doyu studies they were not $[113,114]$. This difference in experimental design may explain the conflicting results.
Collagen is the major component of the ECM and several groups have shown an increase in collagen I and III mRNA after nerve injury as well as functional improvement with exogenous administration [108,115-118]. In the current study, we used an antibody that detected both collagens I and III and found no significant change in levels between day 0 and day 28 in the proximal and distal segments. In the guide there was an early return to baseline protein levels by day $\leq 7$ followed by a significantly higher than baseline expression level at day 21 and a significantly lower level than baseline level by day 28 suggesting that, at least at the protein level, the role of collagens I/III is predominantly in the regenerating portion of the nerve.

Nidogen is a component of the basement membrane. Nidogen protein and mRNA levels have been shown to be up-regulated post transection injury [15] and nidogen appears to be required for neurite outgrowth after axotomy [119]. Our results support these findings as we found an increase in nidogen levels early in the regenerative process with a significant increase by $\leq 7$ days in all segments. The guide contents displayed a biphasic increase in the guide with significant peaks at $\leq 7$ and 21 days and baseline levels at the 14 and 28 days. Clearly nidogen plays a role in many aspects of the regenerative process.

The chondroitin sulphate proteoglycan, versican, isoform V2 has been shown to be an inhibitor of axonal growth while V1 has been shown to promote neurite outgrowth [120-122]. We looked at the versican V0/V1 isoforms and found a significant increase in the proximal and guide segments that peaked at 14 days followed by a slight decline to the end of the study period consistent with these reports. Interestingly, versican levels remained low throughout the experiment in the distal segment suggesting that versican plays more of a role in the proximal region of the regenerating nerve during the timeframe we analyzed.

Not surprisingly, cluster analysis of protein expression over time did not always separate the proteins into the functional groups we defined, but other interesting patterns were revealed (Figure 6). In the proximal section, increased expression of $\mathrm{N}$-cadherin was recorded throughout the regenerative period consistent with its reported role in cell migration and expression in cells of mesenchymal origin. In embryoid bodies, the timing and spatial distribution of versican expression correlates with the appearance and localization of N-cadherin [123]. In this study, N-cadherin and versican expression clustered together in the proximal segment of the regenerating nerve, suggesting that the regenerative events in the proximal nerve may mimic the processes that occur in early development. 
Analysis of expression levels in the guide content is particularly interesting as this compares intact nerve (day 0 expression levels) to the regenerate which, at least for the early time points, contains no nerve. It is not surprising that a greater number of proteins show an initial decline in this segment, but interestingly many are up-regulated even at the earliest time point. In the guide segment groupings more closely follow functional roles. For example, all of the ECM proteins are represented in a single branch (early up-regulated expression) and the majority of the adhesion and motility proteins in the other (early down-regulated expression). The pattern of expression correlates to the temporal role of these proteins groups in the regenerative process where ECM proteins play an early role in the matrix phase and adhesion and motility proteins a later role in the cellular phase of regeneration. GAP-43 is clustered in the upregulated branch and grouped closely with laminin. A functional relationship between GAP-43 and laminin has been implicated in several other studies and this expression pattern may reflect the complex role of GAP-43 in the regenerative process $[124,125]$.

\section{Conclusions}

The expression of multiple cellular and extracellular molecules is finely orchestrated and integrated leading to the regeneration of a new nerve. Past work using this or similar models of peripheral nerve regeneration have taken a reductionist approach evaluating the contribution of individual or small numbers of proteins in the regenerative process. The RPPA approach taken in this study allows expression profiling of multiple proteins from a large number of samples simultaneously. In this study we focused on proteins known to be involved in the regenerative process and with known expression profiles. The results both validated previous observations and provided new detail and complexity, but the application can be easily expanded to include any protein with a suitable, validated antibody including posttranslational modifications such as phosphorylation. In this study we have demonstrated that RPPA is a reliable, high-throughput approach for the analysis of overall protein expression profiles with the potential to identify the temporal sequence of events underlying complex, multifaceted, biological processes.

\section{Methods}

\section{Surgical procedure}

All animal experiments were performed with the approval of the Institutional Animal Care and Use Committee at Lahey Clinic. Forty male Sprague Dawley rats weighing between 225-250 g served as the model for nerve guide repair. All animals were anesthetized via an intraperitoneal injection of $45 \mathrm{mg} \mathrm{kg}^{-1}$ sodium pentobarbital. All underwent an initial surgery during which the right sciatic nerve was exposed via a three centimeter incision made just posterior to the femoral head. The dissection was carried down through the gluteal muscle at which point the sciatic nerve was identified. The remainder of the dissection was performed under an operating microscope at $30 \times$ magnification. This same approach was carried out during a second harvesting procedure.

A length of at least $20 \mathrm{~mm}$ of nerve was exposed. A $10 \mathrm{~mm}$ section was removed via sharp transection with straight micro-scissors leaving at least a $5 \mathrm{~mm}$ proximal and distal sciatic nerve stump. A $14 \mathrm{~mm}$ long polyethylene nerve guide ( $1.67 \mathrm{~mm}$ ID, Becton Dickinson) was sutured in place with 10-0 nylon suture, using a horizontal mattress stitch. The suture was placed $2 \mathrm{~mm}$ from the end of the guide and through the epineurium on each respective nerve stump. The full circumference of each stump was therefore drawn entirely inside the guide with $2 \mathrm{~mm}$ of length lying inside each end of the guide, resulting in the proximal and distal stumps positioned $10 \mathrm{~mm}$ apart. The $10 \mathrm{~mm}$ resected section of nerve was divided into two $5 \mathrm{~mm}$ sections $(5 \mathrm{~mm}$ to act as a per-animal control, and $5 \mathrm{~mm}$ to be used for antibody validation) and the two sections were placed in individual tubes, and frozen immediately in liquid nitrogen. The gluteal muscle was then closed with three buried interrupted 3-0 chromic sutures and the skin was closed with a running 4-0 braided polyglycolic acid suture.

At each time point ( $\leq 7,14,21$, and 28 days), 10 rats underwent a second procedure to harvest the proximal and distal nerve ends and the contents of the guide. All adhesions on the guide were carefully taken down with sharp dissection under the operating microscope. Sharp transection of the proximal and distal stump was carried out, $5 \mathrm{~mm}$ from each end of the guide, with straight micro-scissors. The entire specimen, proximal and distal stumps within the guide, was taken out as one piece. The 10-0 nylon sutures were cut and the remaining tissue was separated into proximal and distal nerve stumps and solid guide contents. Proximal and distal segments included a total of $7 \mathrm{~mm}$ of nerve $(2 \mathrm{~mm}$ of stump within the guide and $5 \mathrm{~mm}$ of additional nerve). At each time point of $\leq 7,14,21$, and 28 days there were $5,2,6$, and 4 rats with solid material spanning the guide, respectively (see Table 1 for experimental overview). Solid guide content was defined as any matrix or tissue that could be macroscopically retrieved from the lumen of the nerve guide. The guide content segment was comprised of only regenerated material and not the nerve stumps themselves. Only tissue from animals with solid guide content was included in the analysis. All tissue was frozen immediately in liquid nitrogen. 


\begin{tabular}{lccc}
\hline & $\begin{array}{c}\text { Number of Animals Included in Day 0 (Baseline) } \\
\text { Measurements }\end{array}$ & $\begin{array}{c}\text { Number of Rats Harvested at } \\
\text { End Point }\end{array}$ & $\begin{array}{c}\text { Number of Rats with Solid Guide Contents } \\
\text { at End Point }\end{array}$ \\
\hline $\begin{array}{c}\text { Day } \leq \\
\mathbf{7}\end{array}$ & 40 & 10 & 5 \\
\hline $\begin{array}{c}\text { Day } \\
\mathbf{1 4}\end{array}$ & & 10 & 2 \\
\cline { 1 - 3 } $\begin{array}{c}\text { Day } \\
\mathbf{2 1}\end{array}$ & & 10 & 6 \\
\hline $\begin{array}{c}\text { Day } \\
28\end{array}$ & & 10 & 4 \\
\hline
\end{tabular}

At each time point proximal, distal and solid guide contents were harvested from each animal. Only tissue from animals with solid guide content was included in the analysis

\section{Antibody validation}

Nerve lysate for antibody validation was prepared by crushing a pooled sample of the excised normal $5 \mathrm{~mm}$ nerve segments under liquid nitrogen, using a mortar and pestle. The finely ground tissue was lysed in hot sample buffer $(2 \times$ ESB - $0.08 \mathrm{M}$ Tris, $\mathrm{pH}$ 6.8; 0.07 M SDS, 10\% glycerol, $0.001 \%$ bromophenol blue and $1 \mathrm{mM} \mathrm{CaCl}_{2}$ ) and sheared through a 26 -gauge needle. $\beta$-mercaptoethanol (1\%) was added to each sample which was boiled for 5 min. The resulting lysate was loaded across the top of a 7.5\% polyacrylamide resolving gel, with one lane containing a marker. Proteins were transferred overnight onto nitrocellulose. Membranes were blocked in $10 \%$ milk in TBS with $0.05 \%$ Tween-20, cut into strips and placed on primary antibody overnight at $4^{\circ} \mathrm{C}$. Blots were washed in TBS with $0.05 \%$ Tween-20, three times for 15 min each, and secondary antibody linked to horseradish peroxidase was incubated with the blots for $60 \mathrm{~min}$ at room temperature. Blots were then washed as described above and developed with an ECL kit (Amersham, Arlington Heights, IL). Only antibodies that produced a single band by western blot analysis were used for RPPA.

\section{Antibodies}

Validated antibodies used were: NGF (Epitomics, Burlingame, CA); Nidogen and FGF1 (Santa Cruz Biotechnology, Santa Cruz, CA); CNTF and FAK (Millipore, Billerica, MA); FGF2, Fibronectin, GAP-43, E-cadherin and $\beta$-catenin (BD Biosciences, San Jose, CA) EGF and laminin-1 gamma-1 (R\&D Systems, Minneapolis, MN); Collagen Type I/III (Calbiochem, San Diego, CA); Versican (Sigma-Aldrich, St. Louis, MO); and N-cadherin (Zymed, San Francisco, CA). The manufacturer of the fifteen antibodies as well as the concentrations used in RPPA and western blot are shown in Table 2 .

\section{Preparation of tissue lysates}

Each nerve sample was crushed under liquid nitrogen with a clean mortar and pestle and suspended in $1.0 \mathrm{ml}$ ice-cold PBS and centrifuged at $4000 \mathrm{rpm}$ for $2 \mathrm{~min}$.
After removing the PBS, a volume of lysis buffer, composed of 9 M Urea, 4\% Chaps, 2\% Pharmalyte $\mathrm{pH} 8.0$ 10.5 and $65 \mathrm{mM}$ Dithiothreitol, equal to the size of the pellet, was added and aspirated up and down 3 times. Samples were centrifuged at 14,000 rpm for $30 \mathrm{~min}$. The supernatant was collected and stored at $-80^{\circ} \mathrm{C}$ and the pellet was discarded. All steps following the initial PBS wash were performed at $4^{\circ} \mathrm{C}$. Ten, 2-fold serial dilutions were made from each lysate with a buffer containing $6 \mathrm{M}$ urea, 2.7\% CHAPS, 1.3\% Pharmalyte (pH 8.010.5), and $43.6 \mathrm{mM}$ Dithiothreitol $[126,127]$.

\section{Reverse-phase protein arrays}

Samples were arrayed using the Aushon 2470 solid pin, contact microarrayer equipped with $185 \mu \mathrm{m}$ pins (Aushon BioSystems, Billerica, MA). The print matrix was a nitrocellulose-cast glass slide (Grace BioLabs, Bend, OR). Each slide contained 10, 2-fold serial

Table 2 Antibody Name, Vendor, and Dilutions Used for Western Blotting and RPPA Applications

\begin{tabular}{lll}
\hline Antibody Name & Vendor & Dilution \\
\hline NGF-b & Epitomics & $1: 500$ \\
\hline Nidogen-1 (H-200) & SCBT & $1: 500$ \\
\hline CNTF (4-68) & Millipore & $1: 100$ \\
\hline FGF2 (basic) & BD Biosciences & $1: 500$ \\
\hline FGF1 (acidic) & SCBT & $1: 100$ \\
\hline EGF & R \& D Systems & $1: 250$ \\
\hline Laminin-1 gamma1 & R \& D Systems & $1: 1000$ \\
\hline Collagen type I/III & Calbiochem & $1: 300$ \\
\hline Fibronectin & BD Biosciences & $1: 5000$ \\
\hline GAP-43 & BD Biosciences & $1: 1000$ \\
\hline FAK & Millipore & $1: 500$ \\
\hline Versican V0/N1 & Sigma-Aldrich & $1: 1000$ \\
\hline E-cadherin & BD Biosciences & $1: 500$ \\
\hline N-cadherin & Zymed & $1: 500$ \\
\hline$\beta$-catenin & BD Biosciences & $1: 1000$ \\
\hline & & \\
\hline
\end{tabular}


dilutions of each sample and included a technical replicate totaling 3,360 lysate spots per slide. All printing was carried out at $80 \%$ relative humidity.

\section{Developing}

Printed nitrocellulose-coated slides were washed for two 15-min periods in deionized water. Slides were blocked for $1 \mathrm{~h}$ in I-Block (Life Technololgies-0.2\% I-Block, $0.01 \%$ Tween-20 in phosphate buffered saline) with continuous shaking at room temperature. Immunostaining of microarrays was performed on an automated stainer (Autostainer Plus, Dako, Carpinteria, CA) using a tyramide-based catalyzed signal amplification system according to the manufacturer's protocol (K1500, Dako, Carpinteria, CA). A negative control was included using a non-specific antibody solution (Dako, Carpinteria, CA) substituting for the primary antibody.

\section{Image processing \& quantification}

The slides were scanned at 2400 dpi resolution in an uncompressed, 16-bit TIFF image format using an optical flatbed scanner. Images were processed by the PSCAN and ProteinScan (version 0.21) programs written using Matlab software (MathWorks, Natick, MA) by the National Institutes of Health (NIH campus, Bethesda, $\mathrm{MD})$. Outliers traceable to defects in the arrays were eliminated and the data were analyzed. The numerical output for each sample was generated by a modified Dose Interpolation algorithm, $\mathrm{DI}_{25}$ [128]. ProteinScan is a program package that automates the modified DI algorithm. The $\mathrm{DI}_{25}$ value of each nerve sample was normalized for total protein concentration determined by colloidal gold staining.

\section{Statistical analysis}

The protein intensity data was log-transformed to ensure data normality. To investigate the spatial and temporal differences in the protein expression levels, a linear mixed effects model was applied to each protein separately. The models contained fixed effects for different times and sample types and are adjusted for baseline protein expression levels. To account for correlated data structure random rat effect was used in the models. To determine which particular times and samples were significantly different, Scheffe's test [129] was used. The significance results were presented as q-values, false discovery rate computed based on $\mathrm{p}$-values to adjust for multiple testing [[130,131], see Additional file 1-q values]. All statistical analyses were performed using $R$ version 2.9.1 [132] and $\mathrm{R}$ packages nlme [133] and qvalue [134]. The clustering and heatmaps were produced using dChip software [135-137]. Heatmap data was rowstandardized to have a mean of 0 .

\section{Additional material}

Additional file 1: q-values; The statistical significance of expression data was determined and results are presented as q values, false discovery rate adjusted $\mathrm{p}$-values.

\section{Abbreviations}

ECM: Extracellular matrix; NGF: Nerve growth factor; FGF: Fibroblast growth factor; CNTF: Ciliary neurotrophic factor; RPPA: Reverse phase protein array; GAP-43: Growth associated protein 43; FAK: Focal adhesion kinase; EGF: Epidermal growth factor

\section{Acknowledgements}

This work was supported by a grant from the Leisa V. Clayton Foundation and the Robert E. Wise, MD Research and Education Foundation.

\section{Author details}

${ }^{1}$ Tissue Engineering Laboratory, Lahey Clinic Medical Center, Burlington, Massachusetts, USA. ${ }^{2}$ Ian C. Summerhayes Cell and Molecular Biology Laboratory, Lahey Clinic Medical Center, Burlington, Massachusetts, USA ${ }^{3}$ Institute for Clinical Research and Health Policy Studies, Tufts Medical Center, Boston, Massachusetts, USA. ${ }^{4}$ Aushon BioSystems Inc., Billerica, Massachusetts, USA. ${ }^{5}$ Department Surgery, Section of General Surgery, Saint Joseph Mercy Hospital, Ann Arbor, Michigan, USA. ${ }^{6}$ Department of Plastic and Reconstructive Surgery, Lahey Clinic Medical Center, Burlington, Massachusetts, USA.

\section{Authors' contributions}

CRL and JVM performed animal surgeries. CRL performed antibody validation experiments, reverse phase microarray processing and assisted with manuscript preparation. DJB contributed to study design, data interpretation, and critical manuscript review. TL performed statistical analysis. $\mathrm{AHH}$ contributed to study design and data interpretation, performed reverse phase microarray printing and drafted the manuscript. JAperformed reverse phase microarray printing and critical review of the manuscript. ICS contributed to study design and data interpretation. KMR-C contributed to study design, data interpretation, and critical review of the manuscript. All authors read and approved the final manuscript.

\section{Competing interests}

$\mathrm{AHH}$ and JA were employees of Aushon Biosystems (manufacturer of the 2470 microarrayer) at the time that this study took place. AHH's affiliation at the time of publication is with Lahey Clinic.

Received: 19 September 2011 Accepted: 10 February 2012

Published: 10 February 2012

\section{References}

1. Noble J, Munro CA, Prasad VS, Midha R: Analysis of upper and lower extremity peripheral nerve injuries in a population of patients with multiple injuries. J Trauma 1998, 45(1):116-122.

2. Terenghi G: Peripheral nerve regeneration and neurotrophic factors. $J$ Anat 1999, 194(Pt 1):1-14.

3. Abe N, Cavalli V: Nerve injury signaling. Curr Opin Neurobiol 2008, 18(3):276-283

4. Lundborg G, Dahlin LB, Danielsen N, Gelberman RH, Longo FM, Powell HC, Varon S: Nerve regeneration in silicone chambers: influence of gap length and of distal stump components. Exp Neurol 1982, 76:361-375.

5. Danielsen N, Dahlin LB, Lee YF, Lundborg F: Axonal growth in mesothelial chambers. The role of the distal nerve segment. Scand J Plast Reconstr Surg 1983, 17(2):119-125

6. Fu SY, Gordon T: The cellular and molecular basis of peripheral nerve regeneration. Mol Neurobiol 1997, 14:(1-2):67-116.

7. Ide C: Peripheral nerve regeneration. Neurosci Res 1996, 25(2):101-121.

8. Parrinello S, Napoli I, Ribeiro S, Digby PW, Fedorova M, Parkinson DB, Doddrell RD, Nakayama M, Adams RH, Lloyd AC: EphB signaling directs peripheral nerve regeneration through Sox2-dependent Schwann cell sorting. Cell 2010, 143(1):145-155. 
9. Gallo G, Lefcort FB, Letourneau PC: The trkA receptor mediates growth cone turning toward a localized source of nerve growth factor. $J$ Neurosci 1997, 17(14):5445-5454.

10. Dodla MC, Bellamkonda RV: Differences between the effect of anisotropic and isotropic laminin and nerve growth factor presenting scaffolds on nerve regeneration across long peripheral nerve gaps. Biomaterials 2008, 29(1):33-46.

11. Brushart TM: Motor axons preferentially reinnervate motor pathways. J Neurosci 1993, 13(6):2730-2738

12. Abernethy DA, Rud A, Thomas PK: Neurotropic influence of the distal stump of transected peripheral nerve on axonal regeneration: absence of topographic specificity in adult nerve. J Anat 1992, 180(Pt 3):395-400.

13. Bailey SB, Eichler ME, Villadiego A, Rich KM: The influence of fibronectin and laminin during Schwann cell migration and peripheral nerve regeneration through silicon chambers. J Neurocytol 1993, 22(3):176-184.

14. Bryan DJ, Tang JB, Holway AH, Rieger-Christ KM, Trantolo DJ, Wise DL, Summerhayes IC: Enhanced peripheral nerve regeneration elicited by cell-mediated events delivered via a bioresorbable PLGA guide. Reconstr Microsurg 2003, 19(2):125-134.

15. Lee HK, Seo IA, Park HK, Park YM, Ahn K, Yoo YH, Park HT: Nidogen is a prosurvival and promigratory factor for adult Schwann cells. J Neurochem 2007, 102(3):686-698.

16. Vanlair C: De la régénération des nerfs périphériques par la procédé de la suture tubulaire. Arch Biol 1882, 3:379-496.

17. Gu X, Ding F, Yang Y, Liu J: Construction of tissue engineered nerve grafts and their application in peripheral nerve regeneration. Progress Neurobio 2010, 93(2):204-230.

18. Siemionow M, Bozkurt M, Zor F: Regeneration and repair of peripheral nerves with different biomaterials: review. Microsurgery 2010, 30(7):574-588

19. Wang KK, Costas PD, Bryan DJ, Eby PL, Seckel BR: Inside-out vein graft repair compared with nerve grafting for nerve regeneration in rats. Microsurgery 1995, 16(2):65-70.

20. Yang Y, Ding F, Wu J, Hu W, Liu W, Liu J, Gu X: Development and evaluation of silk fibrin-based nerve grafts used for peripheral nerve regeneration. Biomaterials 2007, 28(36):5526-5535.

21. Kim YT, Haftel VK, Kumar S, Bellamkonda RV: The role of aligned polymer fiber-based constructs in the bridging of long peripheral nerve gaps. Biomaterials 2008, 29(21):3117-3127.

22. Oh SH, Kim JH, Song KS, Jeon BH, Yoon JH, Seo TB, Namgung U, Lee IW, Lee $\mathrm{JH}$ : Peripheral nerve regeneration within an asymmetrically porous PLGA/Pluronic F127 nerve guide conduit. Biomaterials 2008, 29(11):1601-1609.

23. Bian YZ, Wang Y, Aibaidoula G, Chen GQ, Wu Q: Evaluation of poly(3hydroxybutyrate-co-3-hydroxyhexanoate) conduits for peripheral nerve regeneration. Biomaterials 2009, 30(2):217-225.

24. Bini TB, Gao S, Xu X, Wang S, Ramakrishna S, Leong KW: Peripheral nerve regeneration by microbraided poly(L-lactide-co-glycolide) biodegradable polymer fibers. J Biomed Mater Res A 2004, 68(2):286-295.

25. Matsuyama T, Mackay M, Midha R: Peripheral nerve repair and grafting techniques: a review. Neurol Med Chir (Tokyo) 2000, 40(4):187-199.

26. Dvali L, Mackinnon S: Nerve repair, grafting, and nerve transfers. Clin Plast Surg 2003, 30(2):203-221

27. Nichols CM, Brenner MJ, Fox IK, Tung TH, Hunter DA, Rickman SR, Mackinnon SE: Effects of motor versus sensory nerve grafts on peripheral nerve regeneration. Exp Neurol 2004, 190(2):347-355.

28. Hoke A, Redett R, Hameed H, Jari R, Zhou C, Li ZB, Griffin JW, Brushart TM Schwann cells express motor and sensory phenotypes that regulate axon regeneration. J Neurosci 2006, 26(38):9646-9655.

29. Cohen S, Levi-Montalcini R, Hamburger V: A Nerve Growth-Stimulating Factor Isolated from Sarcomas 37 and 180. Proc Natl Acad Sci USA 1954 40(10):1014-1018.

30. Rich KM, Alexander TD, Pryor JC, Hollowell JP: Nerve growth factor enhances regeneration through silicone chambers. Exp Neurol 1989, 105(2):162-170.

31. Boyd JG, Gordon T: Neurotrophic factors and their receptors in axonal regeneration and functional recovery after peripheral nerve injury. $\mathrm{Mol}$ Neurobiol 2003, 27(3):277-324

32. Huang EJ, Reichardt LF: Neurotrophins: roles in neuronal development and function. Annu Rev Neurosci 2001, 24:677-736.
33. Cordeiro PG, Seckel BR, Lipton SA, D'Amore PA, Wagner J, Madison R: Acidic fibroblast growth factor enhances peripheral nerve regeneration in vivo. Plast Reconstr Surg 1989, 83(6):1013-1021.

34. Walter MA, Kurouglu R, Caulfield JB, Vasconez LO, Thompson JA: Enhanced peripheral nerve regeneration by acidic fibroblast growth factor. Lymphokine Cytokine Res 1993, 12(3):135-141.

35. Midha R, Munro CA, Dalton PD, Tator CH, Shoichet MS: Growth factor enhancement of peripheral nerve regeneration through a novel synthetic hydrogel tube. J Neurosurg 2003, 99(3):555-565.

36. Ohta M, Suzuki Y, Chou H, Ishikawa N, Suzuki S, Tanihara M, Mizushima Y, Dezawa M, Ide C: Novel heparin/alginate gel combined with basic fibroblast growth factor promotes nerve regeneration in rat sciatic nerve. J Biomed Mater Res A 2004, 71(4):661-668.

37. Wang S, Cai Q, Hou J, Bei J, Zhang T, Yang J, Wan Y: Acceleration effect of basic fibroblast growth factor on the regeneration of peripheral nerve through a 15-mm gap. J Biomed Mater Res A 2003, 66(3):522-531.

38. Bryan DJ, Holway AH, Wang KK, Silva AE, Trantolo DJ, Wise D, Summerhayes IC: Influence of glial growth factor and Schwann cells in a bioresorbable guidance channel on peripheral nerve regeneration. Tissue Eng 2000, 6(2):129-138

39. Wells MR, Kraus K, Batter DK, Blunt DG, Weremowitz J, Lynch SE, Antoniades HN, Hansson HA: Gel matrix vehicles for growth factor application in nerve gap injuries repaired with tubes: a comparison of biomatrix, collagen and methylcellulose. Exp Neurol 1997, 146(2):395-402.

40. Sendtner M, Stöckli KA, Thoenen H: Synthesis and localization of ciliary neurotrophic factor in the sciatic nerve of the adult rat after lesion and during regeneration. J Cell Biol 1992, 118(1):139-148.

41. Sahenk Z, Seharaseyon J, Mendell JR: CNTF potentiates peripheral nerve regeneration. Brain Res 1994, 655:(1-2):246-250

42. Newman JP, Verity AN, Hawatmeh S, Fee WE Jr, Terris DJ: Ciliary neurotrophic factors enhances peripheral nerve regeneration. Arch Otolaryngol Head Neck Surg 1996, 122(4):399-403.

43. Lewin SL, Utley DS, Cheng ET, Verity AN, Terris DJ: Simultaneous treatment with BDNF and CNTF after peripheral nerve transection and repair enhances rate of functional recovery compared with BDNF treatment alone. Laryngoscope 1997, 107(7):992-999.

44. Archibald SJ, Krarup C, Shefner J, Li ST, Madison RD: A collagen-based nerve guide conduit for peripheral nerve repair: an electrophysiological study of nerve regeneration in rodents and nonhuman primates. $J$ Comp Neurol 1991, 306(4):685-696.

45. Li ST, Archibald SJ, Krarup C, Madison RD: Peripheral nerve repair with collagen conduits. Clin Mater 1992, 9:(3-4):195-200.

46. Kauppila T, Jyväsjärvi E, Huopaniemi T, Hujanen E, Liesi P: A laminin graft replaces neurorrhaphy in the restorative surgery of the rat sciatic nerve. Exp Neurol 1993, 123(2):181-191.

47. Whitworth IH, Brown RA, Doré C, Green CJ, Terenghi G: Oriented mats of fibronectin as a conduit material for use in peripheral nerve repair. $J$ Hand Surg Br 1995, 20(4):429-436.

48. Bryan DJ, Miller RA, Costas PD, Wang KK, Seckel BR: Immunocytochemistry of skeletal muscle basal lamina grafts in nerve regeneration. Plast Reconstr Surg 1993, 92(5):927-940.

49. Yoshii S, Oka M, Shima M, Taniguchi A, Akagi M: $30 \mathrm{~mm}$ regeneration of rat sciatic nerve along collagen filaments. Brain Res 2002, 949:(1-2):202208.

50. Perlson E, Medzihradszky KF, Darula Z, Munno DW, Syed NI, Burlingame AL, Fainzilber M: Differential proteomics reveals multiple components in retrogradely transported axoplasm after nerve injury. Mol Cell Proteomics 2004, 3(5):510-520.

51. Jiménez CR, Stam FJ, Li KW, Gouwenberg Y, Hornshaw MP, De Winter F, Verhaagen J, Smit AB: Proteomics of the injured rat sciatic nerve reveals protein expression dynamics during regeneration. Mol Cell Proteomics 2005, 4(2):120-132

52. Melle $C$, Ernst G, Grosheva M, Angelov DN, Irintchev A, Guntinas-Lichius $O$, von Eggeling F: Proteomic analysis of microdissected facial nuclei of the rate following facial nerve injury. J Neurosci Methods 2009, 185(1):23-28.

53. Michaelevski I, Segal-Ruder Y, Rozenbaum M, Medzihradszky KF, Shalem O, Coppola G, Horn-Saban S, Ben-Yaakov K, Dagan SY, Rishal I, Geschwind DH, Pilpel Y, Burlingame AL, Fainzilber M: Signaling to transcription networks in the neuronal retrograde injury response. Sci signal 2010, 3(130):ra53.

54. Paweletz CP, Charboneau L, Bichsel VE, Simone NL, Chen T, Gillespie JW Emmert-Buck MR, Roth MJ, Petricoin EF III, Liotta LA: Reverse phase protein 
microarrays which capture disease progression show activation of prosurvival pathways at the cancer invasion front. Oncogene 2001, 20(16):1981-1989.

55. Nishizuka S, Charboneau L, Young L, Major S, Reinhold WC, Waltham M, Kouros-Mehr H, Bussey KJ, Lee JK, Espina V, Munson PJ, Petricoin E, Liotta LA, Weinstein JN: Proteomic profiling of the NCl-60 cancer cell lines using new high-density reverse-phase lysate microarrays. Proc Natl Acad Sci USA 2003, 100(24):14229-14234.

56. Espina V, Mehta Al, Winters ME, Calvert V, Wulfkuhle J, Petricoin EF, Liotta L: Protein microarrays: molecular profiling technologies for clinical specimens. Proteomics 2003, 3(11):2091-2100.

57. Grubb RL, Calvert VS, Wulfkuhle JD, Paweletz CP, Linehan WM, Phillips $\mathrm{J}$, Chuaqui $R$, Valasco A, Gillespie J, Emmert-Buck M, Liotta LA, Petricoin EF: Signal pathway profiling of prostate cancer using reverse phase protein arrays. Proteomics 2003, 3(11):2142-2146.

58. Wulfkuhle JD, Aquino JA, Calvert VS, Fishman DA, Coukos G, Liotta LA, Petricoin EF: Signal pathway profiling of ovarian cancer from human tissue specimens using reverse-phase microarrays. Proteomics 2003, 3(11):2085-2090

59. Hermann PC, Gillespie JW, Charboneau L, Bichsel VE, Paweletz CP, Calvert VS, Kohn EC, Emmert-Buck MR, Liotta LA, Petricoin EF: Mitochondrial proteome: Altered Cytochrome oxidase subunit levels in prostate. Proteomics 2003, 3(9):1801-1810.

60. Liotta LA, Espina V, Mehta Al, Calvert V, Rosenblatt K, Geho D, Munson PJ, Young L, Wulfkuhle J, Petricoin EF: Protein microarrays: meeting analytical challenges for clinical applications. Cancer Cell 2003, 3(4):317-325.

61. Wang K-K, Nemeth IR, Seckel BR, Chakalis-Haley DP, Swann DA, Kuo JW, Bryan DJ, Cetrulo CL Jr: Hyaluronic acid enhances peripheral nerve regeneration in vivo. Microsurgery 1998, 18:270-275.

62. Williams LR, Longo FM, Powell HC, Lundborg G, Varon S: Spatial-temporal progress of peripheral nerve regeneration with a silicone chamber: parameters for a bioassay. J Comp Neurol 1983, 218:460-470.

63. Longo FM, Skaper SD, Manthorpe M, Willimas LR, Lundborg G, Varon S: Temporal changes of neuronotrophic activities accumulating in vivo within nerve regeneration chambers. Exp Neurol 1983, 81:756-769.

64. Verhaagen J, Oesteicher AB, Edwards PM, Veldman H, Jennekens FG, Gispen WH: Light and electron-microscopical study of phosphoprotein B50 following denervation and reinnervation of the rat soleus muscle. $J$ Neurosci 1988, 8(5):1759-1766

65. Verhaagen J, van Hooff CO, Edwards PM, De Graan PN, Oestreicher AB, Schotman P, Jennekens FG, Gispen WH: The kinase C substrate protein B50 and axonal regeneration. Brain Res Bull 1986, 17(6):737-741.

66. Verkade $P$, Oestreicher $A B$, Verkleig AJ, Gispen WH: The increase in B-50/ GAP-43 in regenerating rat sciatic nerve occurs predominantly in unmyelinated axon shafts: a quantitative ultrastructural study. J Comp Neurol 1995, 356(3):433-443.

67. Verkade P, Schrama LH, Verkleij AJ, Gispen WH, Oestreicher AB: Ultrastructural co-localization of calmodulin and B-50/growth-associated protein- 43 at the plasma membrane of proximal unmyelinated axon shafts studied in the model of the regenerating rat sciatic nerve. Neuroscience 1997, 79(4):1207-1218.

68. Plantinga LC, Verhaagen J, Edwards PM, Hol EM, Bar PR, Gispen WH: The expression of B-50/GAP-43 in Schwann cells is up-regulated in degenerating peripheral nerve stumps following nerve injury. Brain Res 1993, 602(1):69-76.

69. Buffo A, Holtmaat AJ, Savio T, Verbeek JS, Oberdick J, Oestreicher AB, Gispen WH, Verhaagen J, Rossi F, Strata P: Targeted overexpression of the neurite growth-associated protein B-50/GAP-43 in cerebellar Purkinje cells induces sprouting after axotomy but not axon regeneration into growth permissive transplants. J Neurosci 1997, 17(22):8778-8791.

70. Van der Zee CEEM, Nielander HB, Vos JP, da Silva SL, Verhaagen J, Oestreicher AB, Schrama LH, Schotman P, Gispen WH: Expression of growth-associated protein B-50 (GAP-43) in dorsal root ganglia and sciatic nerve during regenerative sprouting. J Neurosci 1989, 9(10):3505-3512.

71. Tetzlaff W, Zwiers H, Lederis K, Cassar L, Bisby MA: Axonal transport and localization of B-50/GAP-43-like immunoreactivity in regenerating sciatic and facial nerves of the rat. J Neurosci 1989, 9(4):1303-1313.

72. Tricaud N, Perrin-Tricaud C, Brusés $J$, Rutishauser U: Adherens junctions in myelinating Schwann cells stabilize Schmidt-Lanterman incisures via recruitment of p120 catenin to E-cadherin. J Neurosci 2005, 25(13):3259-3269.

73. Hasegawa M, Seto A, Uchiyama N, Kida S, Yamashima T, Yamashita J: Localization of E-cadherin in peripheral glia after nerve injury and repair. J Neuropathol Exp Neurol 1996, 55(4):424-434.

74. Tada H, Hatoko M, Tanaka A, Kuwahara M, Mashiba K, Yurugi S: The difference in $\mathrm{E}$-cadherin expression between nonvascularized and vascularized nerve grafts: study in the rat sciatic nerve model. J Surg Res 2001, 100(1):57-62

75. Hatoko M, Tanaka A, Kuwahara M, Yurugi S, lioka H, Niitsuma K: Expression of alpha, beta, and gamma catenins in vascularized and nonvascularized nerve grafts during the regeneration process. J Reconstr Microsurg 2003, 19(4):271-278.

76. Bixby JL, Lilien J, Reichardt LF: Identification of the major proteins that promote neuronal process outgrowth on Schwann cells in vitro. J Cell Biol 1988, 107(1):353-361.

77. Matsunaga M, Hatta K, Nagafuchi A, Takeichi M: Guidance of optic nerve fibers by N-cadherin adhesion molecules. Nature 1988, 334(6177):62-64.

78. Cifuentes-Diaz C, Nicolet M, Gondou D, Rieger F, Mege RM: N-cadherin expression in developing adult and denervated chicken neuromansular system: accumulations at both the neuromuscular junction and the node of Ranvier. Development 1994, 120(1):1-11.

79. Hatoko M, Tada H, Tanaka A, Kuwahara M, Yurugi S: The differential expression of $\mathrm{N}$-cadherin in vascularized and nonvascularized nerve grafts: a study in a rat sciatic nerve model. Ann Plast Surg 2001, 47(3):322-327.

80. Thornton MR, Mantovani C, Birchall MA, Terenghi G: Quantification of NCAM and $\mathrm{N}$-cadherin expression in axotomized and crushed rat sciatic nerve. J Anat 2005, 206(1):69-78.

81. Shibuya Y, Mizoguchi A, Takeichi M, Shimada K, Ide C: Localization of Ncadherin in the normal and regenerating nerve fibers of the chicken peripheral nervous system. Neuroscience 1995, 67(1):253-261.

82. Grove M, Komiyama NH, Nave KA, Grant SG, Sherman DL, Brophy PJ: FAK is required for axonal sorting by Schwann cells. J Cell Biol 2007, 176(3):277-282.

83. Tucker BA, Rahimtula M, Mearow KM: Src and FAK are key early signaling intermediates required for neurite growth in NGF-responsive adult DRG neurons. Cell Signal 2008, 20(1):241-257.

84. Grothe C, Wewetzer K: Fibroblast growth factor and its implications for developing and regenerating neurons. Int J Dev Biol 1996, 40(1):403-410.

85. Ebadi M, Bashir RM, Heidrick ML, Hamada FM, Refaey HE, Hamed A, Helal G, Baxi MD, Cerutis DR, Lassi NK: Neurotrophins and their receptors in nerve injury and repair. Neurochem Int 1997, 30:(4-5):347-374

86. Danielsen N, Pettmann B, Vahlsing HL, Manthorpe M, Varon S: Fibroblast growth factor effects on peripheral nerve regeneration in a silicone chamber model. J Neurosci Res 1998, 20(3):320-330.

87. Laird JM, Mason GS, Thomas KA, Hargreaves RJ, Hill RG: Acidic fibroblast growth factor stimulates motor and sensory axon regeneration after sciatic nerve crush in the rat. Neuroscience 1995, 65(1):209-216.

88. Trigg DJ, O'Grady KM, Bhattacharyya T, Reinke M, Toriumi DM: Peripheral nerve regeneration: comparison of laminin and acidic fibroblast growth factor. Am J Otolaryngol 1998, 19(1):29-32.

89. Jungnickel J, Haase K, Konitzer J, Timmer M, Grothe C: Faster nerve regeneration after sciatic nerve injury in mice over-expressing basic fibroblast growth factor. J Neurobiol 2006, 66(9):940-948.

90. Meisinger $C$, Grothe $C$ : Differential regulation of fibroblast growth factor (FGF)-2 and FGF receptor $1 \mathrm{mRNAs}$ and FGF-2 isoforms in spinal ganglia and sciatic nerve after peripheral nerve lesion. J Neurochem 1997, 68(3):1150-1158.

91. Grothe C, Meisinger C, Claus P: In vivo expression and localization of the fibroblast growth factor system in the intact and lesioned rat peripheral nerve and spinal ganglia. J Comp Neurol 2001, 434(3):342-357.

92. Grothe $\mathrm{C}$, Meisinger $\mathrm{C}$, Hertenstein $\mathrm{A}$, Kurz $\mathrm{H}$, Wewetzer K: Expression of fibroblast growth factor-2 and fibroblast growth factor receptor 1 messenger RNAs in spinal ganglia and sciatic nerve: regulation after peripheral nerve lesion. Neuroscience 1997, 76(1):123-135.

93. Eckenstein FP, Shipley GD, Nishi R: Acidic and basic fibroblast growth factors in the nervous system: Distribution and differential alteration of levels after injury of central versus peripheral nerve. J Neurosci 1991, 11(2):412-419. 
94. Ishikawa R, Nishikori K, Furukawa Y, Hayashi K, Furukawa S: Injury-induced reduction of acidic fibroblast growth factor levels in the distal parts of rat sciatic nerve. Neurosci Lett 1992, 135(1):113-116.

95. Toma JG, Pareek S, Barker P, Mathew TC, Murphy RA, Acheson A, Miller FD: Spatiotemporal increases in epidermal growth factor receptors following peripheral nerve injury. J Neurosci 1992, 12(7):2504-2515.

96. Wildering WC, Hermann PM, Bulloch AG: Lymnaea epidermal growth factor promotes axonal regeneration in CNS organ culture. J Neurosci 2001, 21(23):9345-9354.

97. Dubuisson AS, Beuermann RW, Kline DG: Sciatic nerve regeneration across gaps within collagen chambers: the influence of epidermal growth factor. J Reconstr Microsurg 1993, 9(5):341-346.

98. Whitworth $\mathrm{H}$, Brown RA, Dorè $\mathrm{CH}$, Anand P, Green CJ, Terenghi G: Nerve growth factor enhances nerve regeneration through fibronectin grafts. J Hand Surg Br 1996, 21(4):514-522.

99. Heumann R, Lindholm D, Bandtlow C, Meyer M, Radeke MJ, Misko TP

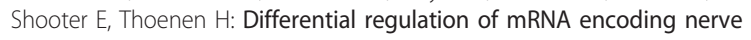
growth factor and its receptor in rat sciatic nerve during development, degeneration and regeneration: role of macrophages. Proc Natl Acad Sci USA 1987, 84(23):8735-8739.

100. Sendtner M, Kreutzberg GW, Thoenen H: Ciliary neurotrophic factor prevents the degeneration of motor neurons after axotomy. Nature 1990, 345(6274):440-441.

101. Sango K, Yanagisawa H, Komuta Y, Si Y, Kawano H: Neuroprotective properties of ciliary neurotrophic factor for cultured adult rat dorsal root ganglion neurons. Histochem Cell Biol 2008, 130(4):669-679.

102. Ito Y, Yamamoto M, Li M, Doyu M, Tanaka F, Mutch T, Mitsuma T, Sobue G: Differential temporal expression of mRNAs for ciliary neurotrophic factor (CNTF), leukemia inhibitory factor (LIF), interleukin-6 (IL-6), and their receptors (CNTFR alpha, LIFR beta, IL-6R alpha and gp130) in injured peripheral nerves. Brain Res 1998, 793:(1-2):321-327.

103. Rabinovsky ED, Smith GM, Browder DP, Shine HD, McManaman JL: Peripheral nerve injury down-regulates CNTF expression in adult rat sciatic nerves. J Neurosci Res 1992, 31(1):188-192.

104. Chernousov MA, Stahl RC, Carey DJ: Schwann cells use a novel collagendependent mechanism for fibronectin fibril assembly. J Cell Sci 1998, 111(Pt 18):2763-2777.

105. Baron-Van Evercooren A, Kleinman HK, Seppa HE, Rentier B, DuboisDalcq M: Fibronectin promotes rat Schwann cell growth and motility. J Cell Biol 1982, 93(1):211-216.

106. Ahmed Z, Brown RA: Adhesion, alignment, and migration of cultured Schwann cells on ultrathin fibronectin fibres. Cell Motil Cytoskeleton 1999, 42(4):331-343.

107. Lefcort F, Venstrom K, McDonald JA, Reichardt LF: Regulation of expression of fibronectin and its receptor, alpha 5 beta 1, during development and regeneration of peripheral nerve. Development 1992, 116(3):767-782.

108. Siironen J, Sandberg M, Vuorinen V, Röyttä M: Expression of type I and III collagens and fibronectin after transection of rat sciatic nerve. Reinnervation compared with denervation. Lab Invest 1992, 67(1):80-87.

109. Matthews GA, Ffrench-Constant C: Embryonic fibronectins are upregulated following peripheral nerve injury in rats. J Neurobio/ 1995 26(2):171-188.

110. Zhang J, Oswald TM, Lineaweaver WC, Chen Z, Zhang G, Chen Z, Zhang F: Enhancement of rat sciatic nerve regeneration by fibronectin and laminin through a silicone chamber. J Reconstr Microsurg 2003, 19(7):467-472.

111. Chen ZL, Strickland S: Laminin $\gamma 1$ is critical for Schwann cell differentiation, axon myelination, and regeneration in the peripheral nerve. J Cell Biol 2003, 163(4):889-899.

112. Grimpe B, Dong S, Doller C, Temple K, Malouf AT, Silver J: The critical role of basement membrane-independent laminin gamma 1 chain during axon regeneration in the CNS. J Neurosci 2002, 22(8):3144-3160.

113. Wallquist W, Patarroyo M, Thams S, Carlstedt T, Stark B, Cullheim S, Hammarberg $\mathrm{H}$ : Laminin chains in rat and human peripheral nerve: distribution and regulation during development and after axonal injury. J Comp Neurol 2002, 454(3):284-293.

114. Doyu M, Sobue G, Ken E, Kimata K, Shinomura T, Yamada Y, Mitsuma T, Takahashi A: Laminin A, B1 and B2 chain gene expression in transected and regenerating nerves: Regulation by axonal signals. J Neurochem 1993, 60(2):543-551.
115. Siironen J, Vuorinen $\mathrm{V}$, Taskinen HS, Röyttä M: Axonal regeneration into chronically denervated distal stump.2. Active expression of type I collagen mRNA in epineurium. Acta Neuropathol 1995, 89(3):219-226.

116. Siironen J, Vuorio E, Sandberg M, Röyttä M: Expression of type I and II collagen and laminin beta1 after sciatic nerve crush injury. J Peripher Nerv Syst 1996, 1(3):209-221.

117. Nath RK, Mackinnon SE, Jensen JN, Parks WC: Spatial pattern of type I collagen expression in injured peripheral nerve. J Neurosurg 1997, 86(5):866-870.

118. Alluin O, Wittmann C, Marqueste T, Chabas JF, Garcia S, Lavaut MN, Guinard D, Feron F, Decherchi P: Functional recovery after peripheral nerve injury and implantation of a collagen guide. Biomaterials 2009, 30(3):363-373.

119. Lee HK, Seo IA, Suh DJ, Park HT: Nidogen plays a role in the regenerative axon growth of adult sensory neurons through Schwann cells. J Korean Med Sci 2009, 24(4):654-659.

120. Niederöst BP, Zimmermann DR, Schwab ME, Bandtlow CE: Bovine CNS myelin contains neurite growth-inhibitory activity associated with chondroitin sulfate proteoglycans. J Neurosci 1999, 19(20):8979-8989.

121. Schmalfeldt M, Bandtlow CE, Dours-Zimmermann MT, Winterhalter $\mathrm{KH}$, Zimmermann DR: Brain derived versican V2 is a potent inhibitor of axonal growth. J Cell Sci 2000, 113(Pt 5):807-816.

122. Wu Y, Sheng W, Chen L, Dong H, Lee V, Lu F, Wong CS, Lu WY, Yang BB: Versican $\mathrm{V} 1$ isoform induces neuronal differentiation and promotes neurite outgrowth. Mol Biol Cell 2004, 15(5):2093-2104.

123. Shukla S, Nair R, Rolle MW, Braun KR, Chan CK, Johnson PY, Wight TN, McDevitt TC: Synthesis and organization of hyaluronan and versican by embryonic stem cells undergoing embryoid body differentiation. $J$ Histochem Cytochem 2010, 58(4):345-358.

124. Gupta SK, Meiri KF, Mahfooz K, Upasna B, Mani S: Coordination between extrinsic matrix cues and intrinsic responses to orient the centrosome in polarizing cerebellar granule neurons. J Neurosci 2010, 30(7):2755-2766.

125. Cheng H, Huang Y-C, Chang P-T, Huang Y-Y: Laminin-incorporated nerve conduits made by plasma treatment for repairing spinal cord injury. Biochem Biophys Res Commun 2007, 357(4):938-944.

126. Spurrier B, Ramalingam S, Nishizuka S: Reverse-phase protein lysate microarrays for cell signaling analysis. Nat Protoc 2008, 3(11):1796-1808.

127. Spurrier B, Honkanen P, Holway A, Kumamoto K, Terashima M, Takenoshita S, Wakabayashi G, Austin J, Nishizuka S: Protein and lysate array technologies in cancer research. Biotechnol Adv 2008, 26(4):361-369.

128. Nishizuka S, Charboneau L, Young L, Major S, Reinhold WC, Waltham M, Kouros-Mehr H, Bussey KJ, Lee JK, Espina V, Munson PJ, Petricoin E, Liotta LA, Weinstein JN: Proteomic profiling of the $\mathrm{NCl}-60$ cancer cell lines using new high-density reverse-phase lysate microarrays. Proc Natl Acad Sci USA 2003, 100(24):14229-14234.

129. Miller RG Jr: Simultaneous Statistical Inference. 2 edition. New York: Springer; 1981.

130. Storey JD: The positive false discovery rate: a Bayesian interpretation and the -value. Ann Statist 2003, 31(6):2013-2035.

131. Storey JD, Taylor JE, Siegmund D: Strong control, conservative point estimation, and simultaneous conservative consistency of false discovery rates: a unified approach. J R Statist Soc B 2004, 66(Pt 1):187-205.

132. R Development Core Team: R: A language and environment for statistical computing. Vienna, Austria; 2008, ISBN 3-90051-07-0, [http://www.R-project. org].

133. Pinheiro J, Bates D, Debroy S, Sarkar S, the R core team: nlme: Linear and nonlinear mixed effects models. $R$ package 2008, version 3.1-88.

134. Dabney A, Storey JD, Warnes GR: q-value: Q-value estimation for false discovery rate control. $R$ package, version 1.1.

135. Li C, Wong WH: Model-based analysis of oligonucleotide arrays: model validation, design issues and standard error application. Genome Biol 2001, 2(8):RESEARCH0032.

136. Li C, Wong WH: Model-based analysis of oligonucleotide arrays: expression index computation and outlier detection. Proc Natl Acad Sci USA 2001, 98(1):31-36.

137. Parmigiani G, Garret ES, Irizarry RA, Zeger SL: The analysis of gene expression data: methods and software New York: Springer; 2003.

doi:10.1186/1477-5956-10-9

Cite this article as: Bryan et al: Spatiotemporal expression profiling of proteins in rat sciatic nerve regeneration using reverse phase protein arrays. Proteome Science 2012 10:9. 